\title{
CHANGES IN SOUTHWESTERN TASMANIAN FIRE REGIMES SINCE THE EARLY 1800s
}

\author{
by Jon B. Marsden-Smedley
}

(with five tables and one text-figure)

\begin{abstract}
Marsden-Smedley, J.B., 1998 (31:xii): Changes in southwestern Tasmanian fire regimes since the early 1800s. Pap.Proc. R. Soc. Tasm. 132: 15-29. https://doi.org/10.26749/rstpp.132.15 ISSN 0040-4703. School of Geography and Environmental Studies, University of Tasmania, GPO Box 252-78, Hobart, Tasmania, Australia 7001.
\end{abstract}

There have been major changes in the fire regime of southwestern Tasmania over the past 170 years. The fire regime has changed from an Aboriginal fire regime of frequent low-intensity fires in buttongrass moorland (mostly in spring and autumn) with only the occasional high-intensity forest fire, to the early European fire regime of frequent high-intensity fires in all vegetation types, to a regime of low to medium intensity buttongrass moorland fires and finally to the current regime of few fires. These changes in the fire regime resulted in major impacts to the region's fire-sensitive vegetation types during the early European period, while the current low fire frequency across much of southwestern Tasmania has resulted in a large proportion of the region's fire-adapted buttongrass moorland being classified as old-growth. These extensive areas of old-growth buttongrass moorland mean that the potential for another large-scale ecologically damaging wildfire is high and, to avoid this, it would be better to re-introduce a regime of low-intensity fires into the region.

Key Words: fire regimes, fire management, southwestern Tasmania, Aboriginal fire, history.

After much fatigue in getting through, we suddenly, on reaching the top of the hill, opened into ground recently burnt, with a most beautiful valley extending SW, beneath us. The whole of this ground had been burnt, apparently immediately before the late snow, and I conclude, by the natives. The valley had the appearance, at a distance, of undergoing all the processes of agriculture, - some parts looking like freshly ploughed fields; and again, other parts possessing the most beautiful verdure from the sprouting of the young grasses and rushes.

(William Sharland in 1832 on the Loddon Plains, southwestern Tasmania.)

\section{INTRODUCTION}

Recurrent fire is a characteristic part of many wildland environments. This is particularly the case in southwestern and western Tasmania, where many thousands of years of human land use have contributed to the genesis of a rich mosaic of fire-tolerant and fire-sensitive vegetation types. These communities are typically juxtaposed and range from the highly fire-tolerant and fire-dependent buttongrass moorlands, through the increasingly fire-sensitive but still fire-dependent wet scrub and wet eucalypt forest to the firesensitive rainforest and coniferous heath communities.

Worldwide, there is an increasing need for active fire management in fire-adapted vegetation, due to the interdependence between fire and vegetation, cessation of burning by traditional societies, enhanced awareness of ecological values, increasing human pressures (of both economy and population) and wildland fragmentation.

The vegetation patterns of southwestern Tasmania are far from unaffected by humans. In this region, humans are responsible for the majority of fires (Marsden-Smedley 1997), and variation in the fire regime is one of the dominant factors determining the balance between the major vegetation assemblages (Jackson 1968). Jackson postulated that, in the absence of fire, rainforests and rainforest-scrub would dominate the vegetation, with the only significant exceptions probably being sites with highly waterlogged soils and/or extreme levels of climatic exposure. Fire acts to modify these vegetation distributions, greatly increasing the area of the fire-adapted moorland, wet scrub and wet eucalypt forest. There is considerable anecdotal evidence for major changes in the fire regime of southwestern Tasmania since the removal of the Tasmanian Aborigines in the 1830s. Historical and contemporary reports suggest that there were frequent fires before about the 1940s, with major fires occurring in the 1890s and 1930s. There are also very extensive areas of fire-sensitive vegetation which appear to have been degraded by fire (Brown 1988, Peterson 1990, Robertson \& Duncan 1991).

This paper examines some of these issues. If changes in the fire regime did occur, this would have major implications for fire management and ecological processes in southwestern Tasmania. This would be due, at least in part, to the interactions between the time since fire and fire behaviour. For example, should we be performing active fire management in southwestern Tasmania or maintaining the current policy of benign neglect (Brown 1996)? Therefore, in order to assess the options for management in southwestern Tasmania objectively, information is required as to the fire history of the region.

\section{METHODS OF ASSESSING FIRE REGIMES}

Information on the fire regime of southwestern Tasmania was collated from published papers, fire history records, historical records, aerial photographs and site records. The area assessed consisted of the Southwest and FranklinGordon National Parks and those parts of the Southwest Conservation Area that are on Cape Sorell or adjacent to the King River and Macquarie Harbour. This region has a total area of about 1227200 ha. 
Attempts were also made to characterise the fire regime likely to be utilised by the Tasmanian Aborigines. This regime was determined using published papers, fire behaviour theory and observations of ecological processes in southwestern Tasmania.

\section{Published papers}

Historical records of fires were assessed. In these records, up to about the $1930 \mathrm{~s}$, the prevailing attitude was that it was an advantage to burn-off the country when performing exploration and/or building access tracks (see pp.19-22). As a result, about two thirds of these records contain extensive references to the areas burnt and the type of fires used. In particular, the following were used: Tasmanian House of Assembly Journal; Legislative Council Journal, The Mercury [newspaper]; Explorers of Western Tasmania (Binks 1980); Trampled Wilderness (Gowlland \& Gowlland 1976); Tasmanian Mail; Notes on forest classification and fire occurrence (Gilbert 1978); Fires in the Tasmanian bush (Gilbert 1979) and History of Emergency Events 1 (State Emergency Service 1990). The unpublished records in the Archives Office of Tasmania were also extensively used. The historical records (i.e. records predating the 1930s) assessed for fire histories are listed in Marsden-Smedley (1997).

These records give a good indication of when and where fires occurred between about the 1850 s and the 1930 s but only contain limited information on fire size. These records also mainly document "official" exploration and trackcutting parties and so give only limited information on private parties. Therefore, the historical records need to be used with caution. For example, in some areas, there was considerable private exploration, particularly for Huon pine (Lagarostrobos franklinii), which may have been associated with extensive burning-off. This probably would have been most marked in the lower Gordon and Davey River regions (Perrin 1887, 1898). As a result, although it is not possible to determine the area burnt from the historical records, they probably do give a reasonable indication of when the major fires occurred.

\section{Field Data and Aerial Photograph Interpretation}

Site age (i.e. time since the last fire) information was collated from a total of 161 sites from published sources (in particular, Jarman et al. 1988a). Fire ages were then sampled from an additional 107 sites, to target areas where there were gaps in the stem aging. The sites assessed are shown in MarsdenSmedley (1997). The fire history maps held by the Fire Management Branch, Parks and Wildlife Service, Tasmania, were also used for checking the ages recorded from different sites.

Sites were aged in the field wherever possible by counting banksia (Banksia marginata) nodes (Bell 1983, Jarman et al. 1988a), with species annual rings being used where banksias were absent. Where possible, ring counts were made from tea-tree species, due to their reliable, easily counted rings. The tea-tree species used included shiny teatree (Leptospermum nitidum), manuka (L. scoparium), L. glaucescens and woolly tea-tree $L$. lanigerum). Where teatree species were not present, white waratah (Agastachys odorata) and/or eucalypts (Eucalyptus coccifera and E. nitida) were used, but these species frequently displayed poor ring structure, resulting in problem in determining site age. Paper-bark species (Melaleuca spp.) were not used, since their poor ring structure resulted in an excessive number of individuals being required. Ring counts were made using a dissecting microscope from the lower surface of crosssections cut from just above the ground. These crosssections had been dried and polished with up to 1200 grade sandpaper. A minimum of six individuals were counted at each site. Previous studies (i.e. Marsden-Smedley $1990,1993 \mathrm{a})$ and extensive cross-checking in this project have shown that site age is typically equal to the ring count mode when species are regenerating vegetatively, and equal to the ring count mode plus one when species are regenerating from seed.

In most parts of southwestern Tasmania, major problems occurred in mapping fires older than the 1930s. This was due to the very extensive area burnt in the 1930 s, which removed much of the evidence of the older fires. As a result, the area burnt in the 1890 s has only been estimated, and all other fires older than the 1930s have been recorded descriptively. From the 1930 s on, fire boundaries and areas burnt have been identified from aerial photographs and/or fire history maps.

All available aerial photographs taken of the study area between 1946 and 1970 in the Department of Environment and Land Management Land Information Bureau were examined for fire boundaries (table 1). These aerial photographs were arranged in projects, typically containing five to 18 runs, each of about 30 to 40 photographs. In addition, aerial photographs of the Port Davey, Wedge and King William areas, taken in the mid to late 1970 s, were examined to assess areas inadequately covered by the earlier photographs. In total, about 7000 aerial photographs were examined for fire boundaries.

TABLE 1

Aerial photographs examined for fire boundaries

\begin{tabular}{lll}
\hline Project & Run(s) & Date \\
\hline King William & 1 to 12 & 1946 \\
Styx & 1 to 14 & 1946 \\
St Clair & 6 to 12 & 1947 \\
Adamsons & 1 to 14 & 1948 \\
Arthur & 1 to 3 & 1948 \\
Bathurst & 1 to 10, all ties & 1948 \\
Huntley & 1 to 5 & 1948 \\
Maatsuyker & 1 to 4 & 1948 \\
Picton & 1 to 16 & 1948 \\
South Cape & 1 to 7 & 1948 \\
Lyell & 1 to 14 & 1949 \\
Pedder & 1 to 8, all ties & 1949 \\
Pillinger & 1 to 7 & 1949 \\
Rocky Point & 1 to 4, east tie & 1949 \\
King-Franklin & 1 to 10 & 1953 \\
King William & 5 to 9 & 1953 \\
Macquarie Harbour & 1 to 7 & 1953 \\
Gordon & 1 to 6 & 1958 \\
Tasmania southwest & 1 to 15, all ties & 1960 \\
Port Davey, F367 & 1 to 9 & 1973 \\
Wedge, F366 & 1 to 4 & 1973 \\
King William, F585 & 1 to 4 & 1978 \\
\hline
\end{tabular}


Aerial photographs and fire history maps were used together, in order to standardise the recording of fires on the older aerial photographs. This system also largely overcomes a problem with the fire history maps from the 1960 s and, to a lesser extent, the early 1970 s, when only the larger and/or higher intensity fires were mapped. In general, fire history maps were used for fires after 1975 , whilst aerial photographs were used for fires before 1975 . The ages estimated from aerial photographs were also checked against fire history records and other aerial photographs taken of the same location at different times. Where possible, the fires identified from aerial photographs were aged to the nearest year, using the data from the site records. For some fires, however, this was not possible, and the fires were allocated a decade. Marsden-Smedley (1997) contains a list of all recorded fires in southwestern Tasmania.

The area of different vegetation types burnt in different decades was assessed by comparing the fire history maps generated in this project (see fig. 1) with a vegetation map of the region. This vegetation map was based on a map produced by Kirkpatrick \& Brown (1991) and showed areas of rainforest, eucalypt forest and non-forest. It also showed the original vegetation type in areas flooded for hydro-electric schemes.

In order to assess the amount of subalpine and alpine vegetation burnt, these communities were assumed to occur at altitudes greater than $100 \mathrm{~m}$ below the local treeline $(\mathrm{J}$. B. Kirkpatrick, pers. comm.). The height at which the treeline occurred was assessed from the published literature (e.g. Kirkpatrick 1982, 1984a, b, Kirkpatrick \& Brown 1987, Kirkpatrick et al. 1996, Bridle \& Kirkpatrick 1997). This height, above which the subalpine and alpine vegetation was assumed to occur, varied from $600 \mathrm{~m}$ in the far southwestern corner of the region (e.g. Mt Rugby, Mt Counsel, South West Cape Range), $800 \mathrm{~m}$ in the central and eastern part of the region (e.g. Southern Ranges, Eastern and Western Arthur Ranges, Frankland Range) to $1000 \mathrm{~m}$ in the western and northern parts of the region (e.g. West Coast Range, Frenchmans Cap, Spires, King William Range).

\section{Fire History Map Production}

The information gained from the published papers, fire history records and aerial photographs was used to generate $1: 100000$ scale fire history base maps for southwestern Tasmania. These base maps were used to produce a 1:250 000 fire history map of the whole region, which was then digitised. Fires were assigned to one of the following age classes: $1890 \mathrm{~s}, 1930 \mathrm{~s}, 1940 \mathrm{~s}, 1950 \mathrm{~s}, 1960 \mathrm{~s}, 1970 \mathrm{~s}, 1980 \mathrm{~s}$, 1990 to 1996 . As has already been mentioned, it was not possible to map the area burnt between the 1890 s and 1930s.

\section{FIRE REGIMES IN SOUTHWESTERN TASMANIA SINCE THE 1830s}

There is strong evidence for major changes in fire regime across southwestern Tasmania in the last 170 years. This period can be divided into four broad categories: pre- 1830 (Aboriginal), 1830s to 1930s (early European), 1940 to about 1970 (middle European) and post 1970 (i.e. current).

\section{Aboriginal Fire Regime}

There has been some conjecture in literature regarding Aboriginal occupation of southwestern Tasmania during the late Pleistocene and Holocene. Some authors suggest the region has been, in fact, largely unoccupied since some time during the period 12-8 ka (e.g. Plomley 1966, Cosgrove et al. 1994), while other authors suggest at least seasonal occupation until historical times (e.g. Kiernan et al. 1983, Flanagan 1985, Jones 1993, Thomas 1993a). Whilst little, if anything, can be deduced from the work reported on in this paper regarding the social and/or cultural importance of fire for the Tasmanian Aborigines, much can be deduced as to whether Aborigines occupied the region and, if so, the type of fire regime urilised and its effects on the region's ecology.

At the time of European settlement, there were extensive buttongrass plains throughout southwestern Tasmania (Goodwin 1828, Little 1833, Frankland 1835, 1836, Burn 1842, Lewis \& McPartlan 1859, Calder $1860 \mathrm{a}$, b, c, Sharland 1861, also Plomley 1966, Gowlland \& Gowlland 1976, Binks 1980). Ecologically, it is highly unlikely that such extensive plains would have persisted in the absence of human-mediated fires for more than about 250 to 1000 years (Jackson 1968, Jarman et al. 1988b, Marsden-Smedley 1990). In addition, many of the early reports describe recently burnt buttongrass moorlands. These include J. Kelly in 1815, J. Goodwin in 1828, G. A. Robinson in 1830 and 1833 , W. S. Sharland in 1832 and J. E. Calder in 1840 on Cape Sorell, Vale of Rasselas, along the south and west coasts of Tasmania, Port Davey, Loddon Plains, Wombat Glen and Navarre Plains (Kelly 1816), Goodwin 1828, Plomley 1966, 1991, Calder 1847, 1849, 1860a, b, c, Sharland 1861, also Gowlland \& Gowlland 1976, Binks 1980). For example, in March 1828, J. Goodwin described what appears to be a patchwork of Aboriginal fires in the Vale of Rasselas (Goodwin 1828):

near the Huon River [Gordon River in the Vale of Rasselas] we saw a number of native fires on the hills, and the grass appeared to have been burnt recently and frequently.

A similar situation was described by W. S. Sharland in 1832 near the upper Franklin River, when his party followed what he considered to be an Aboriginal track (Sharland 1861):

We followed the said marsh [Painters Plain] and some burnt ground until it brought us out to a bare hill where a fire had been made by the blacks ...

As a result, the Aborigines must have been active, at least seasonally, throughout most of southwestern Tasmania in the early 1800 s. Similar conclusions regarding Aboriginal land practices have also been made by Thomas (1993a, b).

An indication of just how open the country must have been in the 1820s and 1830s is also given by the speed at which the first Europeans moved across the country. At this time, such open country is highly unlikely to have been the result of European burning and is far more likely to be the result of thousands of years of Aboriginal fire management. For example, William Sharland in 1832 travelled from Lake Vera to near the present location of Bronte Park in two days (Sharland 1861) while Alexander McKay in 1830 travelled from Sarah Island to Elliott Bay 
A 1890 s (mostly $1897 / 98$ )

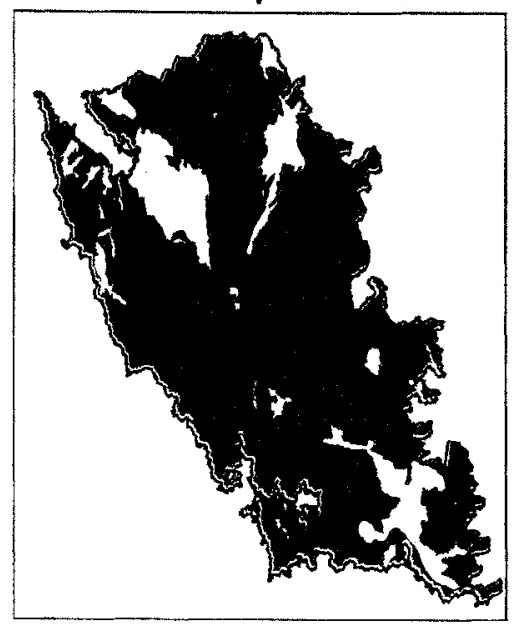

D $1950 \mathrm{~s}$

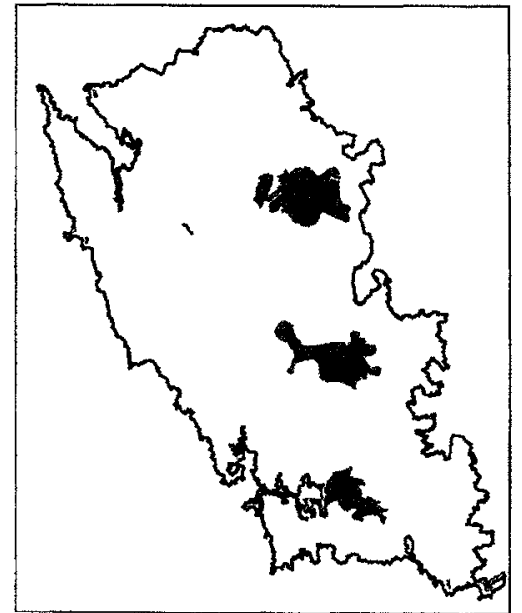

B 1930s (mostly 1933/34)

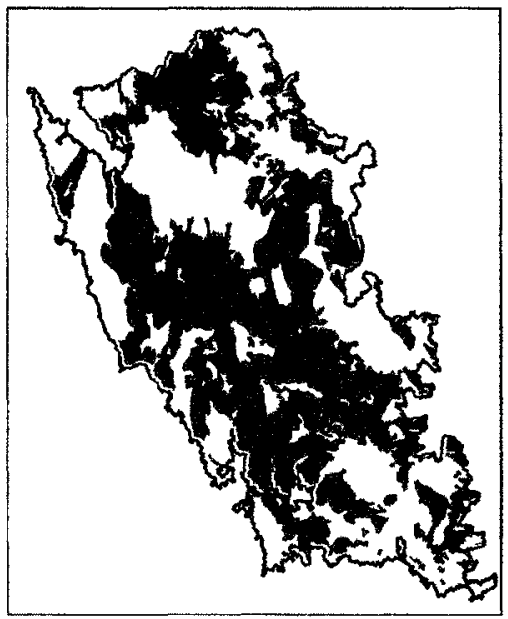

E 1960s

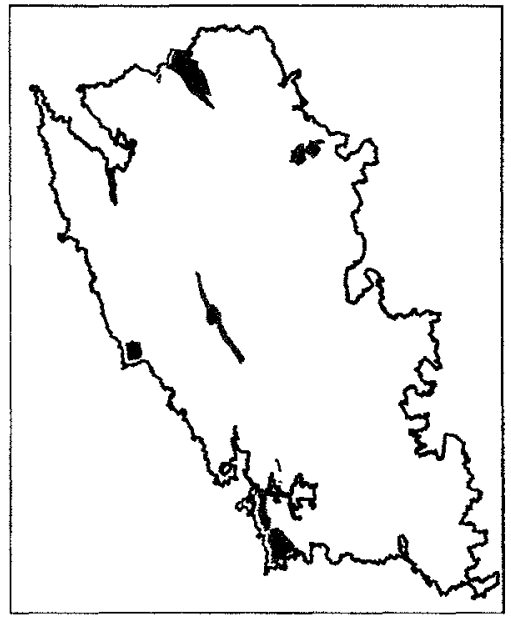

C $1940 \mathrm{~s}$

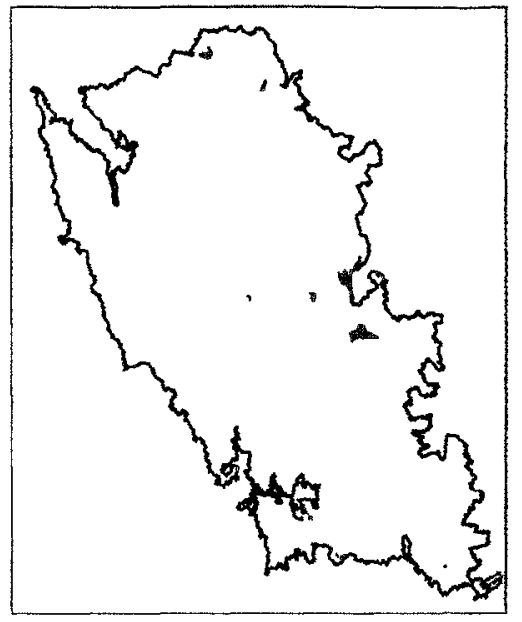

F 1970 s

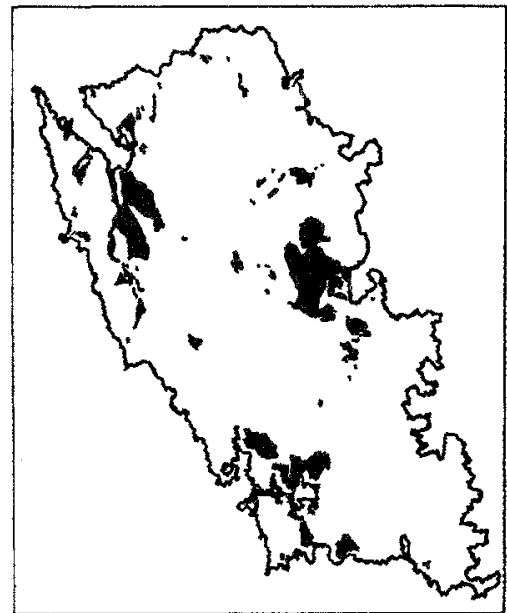

G $1980 \mathrm{~s}$

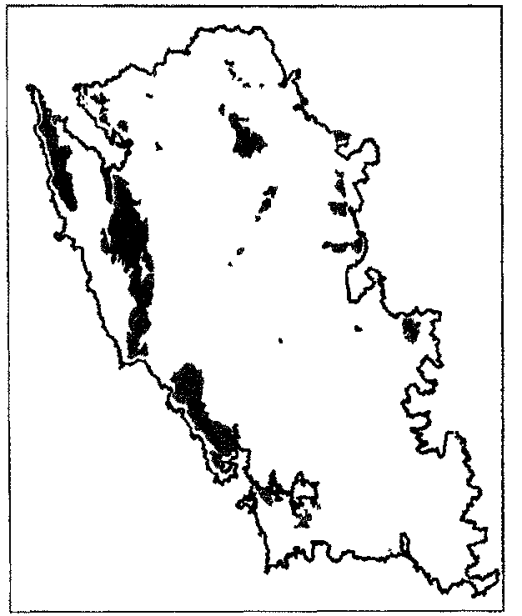

H 1990 to 1996

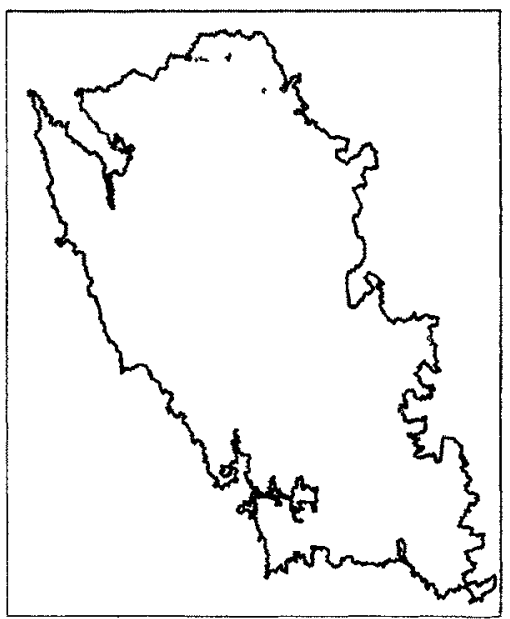

FIG. 1 - Area burnt in the 1890s and since the 1930s in southwestern Tasmania. Note: many of these fires also burnt very extensive areas in other parts of Tasmania. 
in three days (Plomley 1966). In order to achieve such travelling times, the country must have consisted of a series of continuous or near continuous open young buttongrass moorlands. This is supported by the observations by G. A. Robinson in 1833 of the country between Birchs Inlet and Elliott Bay, where he described what appear to be eroded gullies and very open moorlands (Plomley 1966).

The proposed Aboriginal fire regime is one of mostly low-intensity fires under conditions when forested vegetation is too wet to burn. Although fires would have been lit in all seasons (Stockton 1982), in most cases, fires would probably have been restricted to spring, autumn and dry periods in winter. Fires were probably only lit in summer during wetter periods, when fires would have gone out when they burnt up to the moorland-forest boundary. This regime would have resulted in frequent low intensity moorland burns, only occasional fires in eucalypt forest and very few fires in rainforest and alpine vegetation. This regime must have been highly sophisticated and directed towards specific outcomes. The observations of G. A. Robinson on Bruny Island in April 1829, and near Nye Bay on Tasmania's west coast in March 1830 (Plomley 1966) and W. Sharland on the Loddon Plains in March 1832 (Sharland 1861) also support this regime.

The Aborigines also probably used fires to flush game when hunting and to create access tracks (Davies 1846, Roth 1899, Plomley 1966, 1991). There are also several reports describing recently burnt trees with only their bases fire-scarred (Thomas 1991). This would support the proposal that the Aborigines were lighting many small lowintensity fires rather than a few larger higher intensity fires.

This regime of low-intensity fires, mainly in spring and autumn, is analogous to the regime of firestick farming proposed by Jones (1969) and is similar to the fire regime currently being practised by Aborigines in Northern Australia (Jones 1995, Braithwaite 1995, Bowman 1995, also Plomley 1966, Stockton 1982, Binks 1980, Thomas 1991, Thomas \& Hope 1994, Kohen 1995). In such a fire regime, the aim would probably have been to create a large number of small, recently burnt areas surrounded by thicker vegetation.

There are several ways in which the Aborigines could have achieved this control of fire. From the evidence presented by Thomas (1991), it appears that fires were normally lit under conditions when they would be of low intensity and would self-extinguish, although in some cases it appears that fires may have been beaten out using branches (Plomley 1966). This fire management technique is similar to that aimed for in the current low-intensity habitatmanagement burning regime (see Marsden-Smedley 1993a, b, Marsden-Smedley et al. 1998.).

\section{Early European Fire Regime between 1830 and 1940}

Following the removal of the Aborigines, it appears that initially few Europeans visited southwestern Tasmania (i.e. between about 1830 and 1850 ). During the 1830 s to $1840 \mathrm{~s}$, exploration in southwestern Tasmania is only recorded from the middle Gordon River, Lake Pedder, Arthur Plains and upper Franklin River areas (Binks 1980). This was probably due to the small number of Europeans present in Tasmania at that time, the region's remoteness and official discouragement of exploration in order to maintain the isolation of the penal settlement at Sarah
Island (Franks 1958, McRae 1960, Binks 1980). When compared to the fire frequencies and intensities utilised by the Aborigines, the low numbers of people visiting the region in the 1830 s and 1840 s would have resulted in a major reduction in fire frequency and a corresponding increase in fire size and intensity when fires did occur.

By about the 1850 s and 1860 s, there was an extensive network of tracks and routes, which allowed for the reopening up of the region (Cotton 1850, McRae 1960, Gowlland \& Gowlland 1976, Binks 1980). Leading on from this opening up of the country was a major change in fire regime which resulted in the burning of the majority of southwestern Tasmania.

In the available literature, there are numerous references regarding the use of fire in southwestern Tasmania from this period. It appears that the normal method of moving through the region was to burn out a section of country, then follow the resulting easy path. In order to facilitate such burning, it appears that a large number of fires were lit in hot dry (and probably windy) weather, resulting in large, high-intensity fires in all vegetation types. This fire management regime is in marked contrast to the Aboriginal fire management practices.

The, earliest reports of Europeans lighting fires in southwestern Tasmania are probably by J. E. Calder and A. McKay in the middle Gordon River, Lake Pedder and Arthur Plains in March 1837 (Gowlland \& Gowlland 1976). Calder's diary described their fires (Gowlland \& Gowlland 1976):

We burned the ground well filling the atmosphere with smoke ... Fired a vast tract of country ... never saw such a conflagration ...

Parts of the Southern Ranges between Mount Alexandra and Adamsons Peak were probably burnt in the first half of the 1800 s (Perrin 1887). The damage caused by these fires was attributed to the effects of the 1837 frost by Perrin (1987, also Calder 1860a), but fire is a more likely explanation, due to the lack of observations of frost damage in other nearby areas which would be expected to be more susceptible, the distance from which the dead trees were observed (several kilometres) and the extremely frostresistant nature of the species in question (Athrotaxis spp.) Fires also occurred in the Southern Ranges near Mt La Perouse in 1887/88 (Mercury, 11 January 1888), 1897/98 and 1933/34 (see pp. 20-21).

The Arthur, Huon and King William plains and areas in the Vale of Rasselas were burnt in 1850 by the Colonial Survey Office (Cotton 1850, 1851). In 1851, the first large-scale fire reported in southwestern Tasmania occurred. This fire burnt from the Pieman River to Maydena (Gilbert 1979). However, it is possible that the 1851 fire in fact occurred in 1850 and formed part of attempts to modify the region's buttongrass moorlands, such that they would be more suitable for sheep grazing.

In January to May 1859, H.T. Lewis and F. McPartlan led an extensive gold and other minerals search of the Davey River, Hardwood River, Crossing River, Lake Pedder and the south coast of Tasmania. During this time, despite the generally very wet weather, they lit a fire in moorland near the Davey and Hardwood Rivers (Lewis \& McPartlan 1859). In March 1860, J.E. Calder lit large fires near Lake Pedder (Calder 1860c). These fires burnt with high intensities, probably because the area had not been burnt for many years (Lewis \& McPartlan 1859). 
The Loddon Plains were burnt, probably in 1857 by mineral prospectors (Tully 1859). Major fires also occurred in the valleys of the upper Franklin and Collingwood Rivers during W.A. Tully's prospecting expedition of January to March 1859 (Tully 1859). Tully's party in 1859 lit fires which burnt extensive areas, as described in his report of expedition (Tully 1859):

The fire of the previous night had travelled far, burning a large extent of country, and was now raging violently behind us ... vast sheets of flames coming down like an avalanche scarcely one hundred yards distant, and roaring like the seas on a rock-bound shore ... The fires now burning on both sides of the river roared through the scrub, and sheets of flame danced in the thick forest below us, and swept the leaves off the highest trees in an instant ... The country was black for miles; not a speck of green could be seen, except the myrtle forest which clothed the side of Mount Gell.

Extensive burning was performed in the King River and Linda valleys by C. Gould's party in 1862, as described in his report (Gould 1862a):

... upon the 16th [February] proceeded along the plains bordering the Kings River, for a distance of six miles, firing them whenever possible .

The Arthur Plains were burnt in February and March of 1871 by J.R. Scott, W.C. Piguenit and F. McPartlan on their expedition to Port Davey. The 1871 fires were described by J. Hay in March 1871 (Hay 1871; also Scott 1871):

I may mention that had it not been for Mr. Scott's fires running over and clearing a vast deal of the country, we would not have got over the extent of the ground we did in the time.

In 1876, G. C. Meredith led a mineral exploration party to western Tasmania. Their party was prevented from landing at the Pieman River by heavy seas, and so they travelled overland from Macquarie Harbour. Whilst at Macquarie Harbour they lit fires on Cape Sorell (Meredith 1876).

In February to early March 1879 , T. B. Moore burnt much of the country between Birchs Inlet and Port Davey (most of which consists of buttongrass plains). However, T. B. Moore's attempts in mid March and April of the same year to burn the country to the east of Port Davey, including the Crossing and Old River valleys were thwarted by the consistently wet weather.

Extensive fires were lit by track construction parties in the Lake Pedder, Serpentine River, Frankland Range, Rookery Plain and Olga River areas in 1881 and 1894 (Jones 1881, Innes 1896, Gowlland \& Gowlland 1976, Binks 1980). For example, D. Jones whilst cutting a track from the lower Gordon River to the Huon River in 1881 (Jones 1881):

Took advantage of fine day and went ahead to look out best route and fire button-rush ... Whenever we could get a fine day we burned what we could, and the benefit to us was incalculable, rendering the travelling comparatively easy.
J.B. Walker, in his recreation trip of 1887 noted near the Franklin and Collingwood Rivers (Walker 1887, also Innes 1887):

... hill and valley densely wooded, save for lighter spots of open country, and variegated with reddish patches, the mark of extensive bushfires ... To the tourist it is exasperating to see the exquisite native beauty of these forests desecrated and turned into grim. blackness by fires which during this hot summer have swept over so many miles of bush. But doubtless the prospector views it with other eyes, and after reading the graphic legend inscribed on a blazed tree at the foot of Mount Arrowsmith ... we were forced to admit that even these disfiguring fires might have their use in opening up the country, facilitating exploration and diminishing the hardships of these pioneers.

The fires near Frenchmans Cap, referred to by J. B. Walker in 1887, may have been the fires lit by T.B. Moore in February 1887, while cutting a route from the King River to Frenchmans Cap via the Governor River and Mt Finch (Moore 1887), where they

... sent James [Moore] out on the previous day ... to put a match into the country, which is clothed with button grass and tea tree ... We found the fire had done excellent work and was still blazing ahead ... The fires burnt for a week, and cleared the hated button grass and bauera splendidly, in all directions for miles.

Very extensive areas of the buttongrass moorland and wet scrub between Frodshams Pass on McPartlan's South Gordon Track and Joe Page Bay in Bathurst Harbour, along with forests on the slopes of $\mathrm{Mt}$ Bowes, were burnt in February 1898 (Marsden 1898). From the available information, it appears that these fires were not lit during the construction of the Port Davey Track by E.A. Marsden, but are part of a much larger series of fires which burnt very extensive areas throughout southwestern Tasmania that summer.

The $1897 / 98$ fires in western and southwestern Tasmania were extensively reported on in the Mercury (e.g. 31 December $1897 ; 4,6$, 15 January 1898; 6, 10 February 1898) and in the Tasmanian Mail (e.g. 8, 15 January 1898; 19, 26 February 1898). The effects of these fires can also be seen in photographs which were taken between the 1890 s and 1920s and are held in the Archives Office of Tasmania (Marsden-Smedley 1997). In total, the $1897 / 98$ fires appear to have burnt much of the country between the West Coast Range, Hartz Mountains and the Southern Ranges (table 2). If so, then these would have been the largest fires in Tasmania's recorded history, with an area of about 1000000 ha within southwestern Tasmania (fig. $1 \mathrm{~A}$ and see below, table 4).

Fires were also lit around Cox Bight and Melaleuca in 1898 by G.C. Meredith and his brother, during a mineral prospecting trip. These were unlikely to have been major fires, due to the generally wet weather preceding them.

In January to March 1900, T.B. Moore again led a party from Birchs Inlet to Port Davey and, in common with the 1879 trip, extensive fires were lit (Binks 1980, McShane 1982).

In March 1906, W.H. Tyler and W.T. Harper marked out a track along the south coast from Cockle Creek to Cox Bight. During this trip, they burnt Black Hole Plain and 
reported that between Surprise Bay and Rocky Boat Inlet, the country had been fairly recently burnt, probably in 1897/98 (Tyler \& Harper 1906).

In 1907/08, R. Marriott burnt extensive areas between the Vale of Rasselas and the Prince of Wales Range, including the Gell River, Mt Curly and the Denison River (Twelvetrees 1908; also Marriott 1908).

In December 1908, R.A.C. Thirkell cut a track from the Linda Track to the lower Franklin River, via the Loddon Plains, Calders Pass, Lightning Plains, Acheron River and Jane River. His report of the trackcutting noted (Thirkell 1908):

My party have been able to fire the country well, and this will be of great assistance to the prospector next summer.

In 1933/34 there were very extensive fires on the Raglan Range, Loddon and Lightning Plains and near where the Frenchmans Cap Track leaves the Linda Track (Mercury, 3 March 1934, Thwaites 1934, Johnston 1935, Warren 1936, photographs in Philp 1937). In 1936, fires are reported to have been lit near Philps Lead and Lake Vera (Warren 1936), probably by piners and/or mineral exploration parties reopening J. L. Moore's 1900 and R.A.C. Thirkell's 1908 track to the Jane River (see also Abel n.d.). Warren (1936) also reported observing the smoke from fires near the Jane River, Raglan Range, Eldon Range and to the west (probably in the West Coast Range).

Between about the 1910 s and 1930s, in marked contrast to the preceding 60 years, there was a major decrease in the amount of prospecting and exploration activity in southwestern Tasmania. The only significant exception to this decrease appears to be the development of the Adamsfield osmiridium field (Gowlland \& Gowlland 1976) along with small mining fields at Cox Bight (Twelvetrees 1906), Melaleuca, Osmiridium Beach and the Jane River. This decrease in activity was probably due to the realisation that in southwestern Tasmania, with a few exceptions, the potential for significant mineral deposits and/or good agricultural land was very low. This reduction in exploration activity was reflected in the prospecting accounts of Twelvetrees (1908, 1909, 1915), Ward (1908, 1909) and Howard (1927), all of which reported that the access tracks had become very overgrown and blocked with fallen timber. The reduction in exploration activity was also reflected in the Department of Lands and Surveys annual reports for 1910 to 1932 (Parliament of Tasmania Journals). All these annual reports called for additional track construction to be performed, but all of them also reported that in southwestern Tasmania, no existing tracks had been cleared or new tracks constructed. Only five major tracks are known to have been cut during this period. Two of these tracks, Condor's 1915 west coast track and Hales' 1918 track, were cut by the Department of Mines. Condor's 1912 to 1915 west coast track went from Double Cove in Macquarie Harbour to the west coast near Albina Rock, and then south to Port Davey and north to Cape Sorell (Hills 1914, Condor 1915), while Hales' 1918 track went from the Gordon River to the Port Davey track (Hales 1918). In 1910, J. Philp marked out a track from the Linda Track to Frenchmans Cap via the Loddon Plains, Philps Lead and Lake Vera (Philp 1937). No official record appears to exist of the other two tracks which were put in during this period, except that they are shown on the 1960 sketch map of southwestern Tasmania (Department of Mines Tasmania 1960). Both of these tracks were located in the Weld River valley and linked the Huon River valley with the Port Davey Track, with one track linking via the upper Weld River valley and the other via the Snake River valley. The Snake River route is marked on the 1960 map as Giblin's 1924 route. The Weld River Track was originally cut by $\mathrm{H}$. Judd and, subsequently, may have been recut by $\mathrm{C}$. and D. King (who are better known as tin miners at Cox Bight and Melaleuca). This track was also used by a Mr Roberts to access the Jubilee Range for cattle grazing.

The prevailing sentiment of the $1800 \mathrm{~s}$ and early $1900 \mathrm{~s}$ appears to have been that it was advantageous to the prospector to burn sites in order to expose mineral strata, that fire would not hurt healthy forest, and that buttongrass moorlands could be transformed into more productive agricultural land by burning, sowing with pasture grasses and stocking with sheep and cattle. For example, the Chief Government Geologist, W.H. Twelvetrees, proposed in 1908 that areas of moorland, wet scrub and eucalypt forest (Twelvetrees 1908) could:

... be burned off in broad belts, and if this is done much track-making is unnecessary at first. The prospector can see by the line of burned country which way to follow; he can, moreover, get over the country easily, and prospect without difficulty where he desires. Money spent in burning the country in this way is well spent, and benefits the explorer even more than does the cutting of tracks (except of course through timber).

In 1860 , J.E. Calder questioned whether fire would cause deleterious effects to the vegetation (Calder 1860a):

... do bush fires destroy the forests, or even seriously injure sound and living trees? and do we not see the contrary in a hundred cases every summer? If such indeed were the case we ought not to have a tree left in Tasmania.

C. Gould, in 1862, also held to the belief that buttongrass moorlands could be transformed, in that he proposed (Gould 1862a) that the extensive plains in the lower Gordon River and near Macquarie Harbour could

... afford moderate pasture, and are probably susceptible of the same improvement which is found to follow continuous burning and stocking in other parts of the Colony.

These attitudes are also reflected in the Colonial Survey Office reports. For example, H. Cotton in 1850 described the grazing potential of the buttongrass moorlands on the Arthur, Huon, King William Plains and in the Vale of Rasselas (Cotton 1850):

The rough herbage upon these plains have been burnt for the encouragement of the grasses which are found to take its place, and in some parts, especially near Lakes Pedder and Edgar and in the Gordon Valley, the pasture is rich and luxuriant.

Such was the destruction of forest and other vegetation types by wildfires during this period that the issue was addressed by parliamentary reviews of the Tasmanian timber industry in 1887 and 1898 (e.g. Perrin 1887, 1898, Counsel 1898). For example, the Surveyor-General and Secretary for Lands, E.A. Counsel, reported (Counsel 1898) that 
... one of the main points to which I desire to direct especial attention in this Report is the enormous consumption of valuable timber which is in process of being destroyed in the Mining Districts, particularly on the West Coast ... there is a wholesale and reckless destruction of the forest growth, young and old, by bush fires in all directions during many months of the year.

Counsel (1898) also called for changes in the policies for managing forested areas, including

3. That regulations be framed and especial care taken to protect young pine and other trees and plants from destruction.

4. That stringent measures be enacted for prohibiting the lighting of bush fires on unoccupied Crown Lands.

In the accompanying report on forest conservation and management by the Victorian Conservator of State Forests G.S. Perrin, these issues were reiterated in the strongest manner (Perrin 1898):

The bush fires about Lyell, Zeehan, the Pieman and Lake Dora, \&c. have already destroyed timber which it will cost shareholders in the mines many thousands of pounds more than they would otherwise have had to pay ...

All through, however, indiscriminate felling and fierce bush fires have already destroyed large quantities of the useful timber I saw in this district [Zeehan and Mount Lyell] ten years ago, and have completely changed the face of the country.

Perrin (1898) also stated that fire protection in state forests was of the highest importance:

This is a matter of urgent moment to the future of Tasmanian timber supplies ... A stringent Fire Act should be drafted with as little delay as possible ... The presence of the miner on the West Coast has, of course, resulted in the usual gross carelessness, and sometimes malicious vandalism, with which it has been associated elsewhere, and, unless the matter is dealt with promptly and vigorously, timber in this district for mining and other purposes will be completely exhausted within a very few years ... In order to clear prospecting claims it is quite an ordinary custom for the prospector to set fire to the timber and let the flames spread at will over as much of the surrounding country as they can reach.

As a result, large and/or high intensity fires burned across the majority of western and southwestern Tasmania. In particular, major fires are known to have occurred in 1851, $1897 / 98,1914,1933 / 34$ and 1939, with numerous additional fires in other years. It should be noted, however, that the large areas burnt in these fires were probably the result of several smaller fires. The fires recorded between the 1830s and 1930s are shown in table 2, while the areas burnt in the 1890s and 1930s are shown in figure 1.

Some of these fires were very large, in particular the $1851,1897 / 98$ and 1933/34 fires. The 1851 fires are reported to have burned from the Pieman River to Maydena (a distance of over $150 \mathrm{~km}$ in a straight line - Mercury, 10 February 1939, Gilbert 1979). However, as already mentioned, it is possible that the 1851 fire occurred the previous year and formed part of the fires lit by the Colonial Survey Office which were aimed at opening up western Tasmania for sheep grazing (Cotton 1850). The 1897/98 fires burnt extensive areas near Queenstown, Frenchmans Cap, the Huon River, New River Lagoon and many other parts of southwestern Tasmania (see table 2, fig. 1A). The 1933/34 fires burned from the West Coast Range and the Lower Gordon River to Southport Lagoon (a distance of over $200 \mathrm{~km}$ in a straight line - fig. 1B). However, it has not been possible to map the northwestern part of the 1933/34 fires accurately (i.e. around the Raglan Range, Frenchmans Cap and Lightning Plains areas), since this area was reburnt in the much higher intensity 1938/39 fires.

The 1897/98, 1933/34 and 1939 fires all had periods of very high-intensity fire behaviour. For example, the 1933/ 34 fires caused darkness in Hobart between 4 and 5 pm on 9 February 1934 (Mercury, 10 February 1934), while the 1939 fires burned large areas of rainforest with crown fires (in contrast to most rainforest fires), which rarely burn more than about three-quarters of the forest canopy).

The map of the 1890s fires (most of which burned in 1897/98) shown in figure $1 \mathrm{~A}$ was compiled from the information in table 2, newspaper and other historical records, site ages, historical photographs in the Archives Office of Tasmania and the author's personal knowledge of southwestern Tasmania. Since many of the areas burnt in the 1890s were also burnt in the 1933/34 and/or 1938/39 fires, it has not been possible to determine accurately the degree to which the different vegetation types were burnt in the 1890 s fires (i.e. the relative proportions of burnt to unburnt areas within the fire's boundaries). Therefore, the fire boundaries shown in figure $1 \mathrm{~A}$ and the areas shown as burnt in tables 3 and 4 should be taken only as a guide. For the purposes of this paper, within the area shown as burnt in the $1890 \mathrm{~s}$, reasonable estimates of the degree in which the different vegetation types burnt are about $95 \%$ for non-forest, about $90 \%$ for wet eucalypt forest and about $75 \%$ for rainforest, alpine and subalpine areas. For the same reason, (i.e. reburning by the 1930 s fires) it has not been possible to map the fires of the 1900s, 1910s and 1920 s. It should also be noted that the 1890 s, $1933 / 34$ and $1938 / 39$ fires burned very extensive areas outside this project's study area.

These very large fires would best be described as landscapescale fires, in that they burnt very extensive areas, probably taking several weeks to months to do so. Landscape-scale fires appear to have only been contained by major geographic boundaries, such as the major rivers and/or large areas of rainforest, especially those on the lee sides of mountain ranges and/or the coast.

The landscape-scale fires during this period were probably responsible for the destruction of extensive areas of highly fire-sensitive coniferous forest and heath that have been burnt since European settlement in Tasmania (Mercury, 4 Jan. 1898, Perrin 1898; also Brown 1988, Peterson 1990, Robertson \& Duncan 1991). These fires may also have had major impacts on the region's peat soils (Pemberton 1988, 1989, Hannan et al. 1993, Pemberton \& Cullen 1995). 
TABLE 2

Recorded fires in western and southwestern Tasmania between the 1820 s and 1930s

\begin{tabular}{|c|c|c|c|}
\hline Location & Date & Major fire* & Reference \\
\hline \multicolumn{4}{|l|}{ Aboriginal fires } \\
\hline Vale of Rasselas & 1828 & no & Goodwin 1828 \\
\hline Port Davey, Lower Hut Plains, Nye Bay & 1830 & no & Plomley 1966 \\
\hline Loddon Plains & 1832 & no & Sharland 1861 \\
\hline Birchs Inlet-Elliott Bay & 1833 & no & Plomley 1966 \\
\hline \multicolumn{4}{|l|}{ European fires } \\
\hline middle Gordon R., L. Pedder, Arthur Plains & 1837 & yes & Gowlland \& Gowlland 1976 \\
\hline Mt Alexandra to Adamsons Peak & early 1800 s & $?$ & Perrin 1887 \\
\hline Loddon Plains & $1849 ?$ & ? & Tully 1859 \\
\hline Arthur, Huon and King William Plains & 1850 & ? & Cotton 1850,1851 \\
\hline Vale of Rassalas & 1850 & ? & Cotton 1850,1851 \\
\hline Pieman River to Maydena & 1851 & yes & Mercury 10-2-1934, 1-2-1939 \\
\hline Hardwood River, Davey River & 1859 & no & Lewis \& McPartlan 1859 \\
\hline upper Franklin and Collingwood Rivers & 1859 & yes & Tully 1859 \\
\hline Lake Pedder, Frankland Range, Hardwood River & 1860 & $?$ & Calder $1860 c$ \\
\hline King River and Linda Valley & $1861 / 62$ & yes & Gould 1862a \\
\hline Arthur Plains & $1870 / 71$ & $?$ & Hay 1871, Scott 1871 \\
\hline Cape Sorell & 1876 & ? & Meredith 1876 \\
\hline Birchs Inlet to Port Davey & $1878 / 79$ & no & Binks 1980, McShane 1982 \\
\hline Lake Pedder, Frankland Range, Hardwood River & 1881 & no & Jones 1881 \\
\hline D'Entrecasteaux River & $1886 / 87$ & no & Perrin 1887 \\
\hline King River, Mt Fincham, Frenchmans Cap & 1887 & yes & Moore 1887 \\
\hline upper Franklin and Collingwood Rivers & $1887 / 88$ & yes & Innes 1887, Walker 1887 \\
\hline Mt La Perouse & $1887 / 88$ & $?$ & Mercury 11-01-1888 \\
\hline Lake Pedder, Frankland Range, Hardwood River & 1894 & no & Innes 1896 \\
\hline Mt Bowes, Arthur Plains, Huon River & $1897 / 98$ & yes & Marsden 1898 \\
\hline Crossing and Spring Rivers, Melaleuca & $1897 / 98$ & yes & Marsden-Smedley 1997 \\
\hline Southwest Cape Range, Cox Bight & $1897 / 98$ & yes & Marsden-Smedley 1997 \\
\hline Mt Bobs-Boomerang & $1897 / 98$ & yes & Kirkpatrick \& Harwood 1980 \\
\hline Lake St Clair & $1897 / 98$ & yes & Mercury 6-01-1898 \\
\hline Queenstown, Zeehan, Strahan, Tyndall Range & $1897 / 98$ & yes & Mercury 4-01-1898 \\
\hline Raglan Range, King River, Mt Owen, Mt Lyell & $1897 / 98$ & yes & Ward 1908 \\
\hline Lake Vera, Philps Peak & $1897 / 98$ & yes & Philp 1937 \\
\hline Flat Rock Plain & $1897 / 98$ & yes & Marsden-Smedley 1997 \\
\hline Surprise Bay, Tylers Creek, Rocky Boat Inlet & $1897 / 98$ & yes & Tyler \& Harper 1906 \\
\hline Menzies Bluff & $1897 / 98$ & yes & Marsden-Smedley 1997 \\
\hline Pindars Peak, Gordon Gorge, Hartz Mtn & $1897 / 98$ & yes & Archives Office of Tasmania photo \\
\hline Mt Read, Mt Darwin, L. Margaret, Queenstown & $1897 / 98$ & yes & Archives Office of Tasmania photo \\
\hline Cox Bight-Melaleuca & 1898 & no & Meredith 1898 \\
\hline Birchs Inlet to Port Davey & $1899 / 1900$ & no & Binks 1980, McShane 1982 \\
\hline Black Hole Plain & $1905 / 06$ & no & Tyler \& Harper 1906 \\
\hline Gell River, Mt Curly, Denison River & $1907 / 08$ & no & Twelvetrees 1908 \\
\hline Jane River, Lightning Plains?, Loddon Plains? & $1907 / 08$ & no & Thirkell 1908 \\
\hline Raglan Range, Loddon and Lightning Plains & $1933 / 34$ & yes & Thwaites 1934, Johnston 1935 \\
\hline Linda and Frenchmans Cap Tracks junction & $1933 / 34$ & yes & Philp 1937 \\
\hline Loddon Plains, Lake Vera, Raglan Range & $1935 / 36$ & $?$ & Warren 1936 \\
\hline Eldon Range, Jane River & $1935 / 36$ & ? & Warren 1936 \\
\hline West Coast Range, Frenchmans Cap & $1938 / 39$ & yes & B. Bradshaw, pers. comm. \\
\hline
\end{tabular}

* Major fire: yes = large and/or high intensity fire, no = small and/or low intensity fire, $?=$ fire size and/or intensity unknown.

\section{Fire Regime between 1940 and 1970}

Between about 1940 and 1970 another change in the fire regime appears to have occurred. During this time fires were generally small, with the notable exceptions of three fires in the 1950 s (i.e. the Old River, Spires and Lake Pedder fires; fig. 1C). Two of these large fires were lit by mineral exploration parties (i.e. Old River Fire, Mercury; Lake Pedder Fire, D. Pinkard, pers. comm.). The cause of the Spires fire is unknown, but mineral exploration parties were active in this area at this time (Mines Department Annual Reports for 1950 to 1953). Another major change in fire 
TABLE 3

Fire regimes during different periods in southwestern Tasmania

\begin{tabular}{|c|c|c|c|c|c|c|c|c|}
\hline \multirow[b]{3}{*}{ Period } & \multicolumn{8}{|c|}{ Vegetation assemblage } \\
\hline & \multicolumn{2}{|c|}{ Moorland } & \multicolumn{2}{|c|}{ Wet scrub } & \multicolumn{2}{|c|}{ Wet eucalypt forest } & \multicolumn{2}{|c|}{ Rainforest } \\
\hline & Frequency & Intensity & Frequency & Intensity & Frequency & Intensity & Frequency & Intensity \\
\hline Aboriginal, pre-1 830 & high & low & med & med & low & high & low & high \\
\hline early European, $1830 / 1940$ & high & high & high & high & high & high & high & high \\
\hline middle European, 1940/70 & low & low/med & low & med & low & high & low & high \\
\hline currenr, post 1970 & low & variable & low & med & low & high & low & high \\
\hline
\end{tabular}

TABLE 4

Area of different vegetation types burnt in the 1890s and since the 1930s

\begin{tabular}{|c|c|c|c|c|c|c|c|c|c|}
\hline \multirow[b]{3}{*}{ Period } & \multicolumn{9}{|c|}{ Vegetation assemblage } \\
\hline & \multicolumn{2}{|c|}{$\begin{array}{c}\text { Moorland } \\
\text { and wet scrub }\end{array}$} & \multicolumn{2}{|c|}{$\begin{array}{c}\text { Wet eucalypt } \\
\text { forest }\end{array}$} & \multicolumn{2}{|c|}{ Rainforest } & \multicolumn{2}{|c|}{$\begin{array}{l}\text { Subalpine } \\
\text { and alpine }\end{array}$} & \multirow{2}{*}{$\frac{\text { Total }}{\text { ha }}$} \\
\hline & ha & $\%$ & ha & $\%$ & ha & $\%$ & ha & $\%$ & \\
\hline estimated $1890 \mathrm{~s}$ & 690676 & 90.3 & 188516 & 83.3 & 94192 & 38.3 & 25913 & 50.3 & 999296 \\
\hline $1930 \mathrm{~s}$ & 489625 & 64.0 & 51161 & 22.6 & 59364 & 24.1 & 28906 & 56.1 & 629056 \\
\hline $1940 \mathrm{~s}$ & 8257 & 1.1 & 2158 & 1.0 & 356 & 0.1 & 80 & 0.2 & 10851 \\
\hline $1950 \mathrm{~s}$ & 71384 & 9.4 & 4755 & 2.1 & 5096 & 2.1 & 2497 & 4.8 & 83732 \\
\hline $1960 \mathrm{~s}$ & 25743 & 3.4 & 3860 & 1.7 & 3739 & 1.5 & 394 & 0.8 & 33736 \\
\hline $1970 \mathrm{~s}$ & 92349 & 13.1 & 7835 & 3.5 & 4649 & 1.9 & 390 & 0.8 & 105223 \\
\hline $1980 \mathrm{~s}$ & 88947 & 12.6 & 8307 & 3.7 & 7595 & 3.1 & 379 & 0.7 & 105228 \\
\hline 1990 to 1996 & 380 & 0.1 & 456 & 0.2 & 142 & 0.1 & 19 & 0.0 & 997 \\
\hline Total burnt & 1467361 & - & 267048 & - & 175133 & - & 58578 & - & 1968119 \\
\hline
\end{tabular}

Note: the area of different vegetation types has changed since the 1950s, due to the effects of inundation for hydro-electric schemes. Current area of the different vegetation types shown. \% burnt in each decade $=$ the $\%$ of the total area of each vegetation type and not the \% of the total area burnt. See Marsden-Smedley 1997 for the total area of each vegetation type. Areas burnt in the 1890 s corrected for the amount that each vegetation type is estimated to have burnt (see text).

regime during this period is a change to primarily moorland fires, with little forest being burnt (table 4). This change in fire regime is probably the result of changes in cultural attitudes, whereby southwestern Tasmania began to be valued more for its natural assets and less for its mineral and grazing potential; therefore, fewer fires were being lit. The fire regime during the 1940 s to 1960 s would most probably have been one of mostly medium intensity fires in spring and autumn, mainly in moorland communities.

\section{Post 1970 Fire Regime}

Since the 1970 s, there has been a shift to a combination of prescribed burns in selected areas of buttongrass moorland and, effectively, a fire exclusion policy (including the suppression of wildfires) across the rest of the region (Parks and Wildlife Service 1997). It should be noted that there have been marked reductions in the area burnt in prescribed fires in the past decade (table 4). The end result of these practices has been the maintenance of young moorlands in the Lyell Highway, Birchs Inlet, Elliott Bay, Port Davey,
Melaleuca and Cox Bight regions, and the development of old-growth moorlands and wet scrub across most of the rest of the area. In common with the period 1940 to 1970 , few forest fires occurred. The majority of the fires during this period were low intensity, although some fires did have short periods of medium-intensity fire behaviour. For example, the Birchs Inlet and Mulcahy Bay fires both burned about half of the total area during the final afternoon of fire run, resulting about 30000 ha being burnt out in two four-hour periods (i.e. $25 \%$ of the total area burnt between 1980 and $1995 / 96$, burned during about eight hours). The fire regime in the post 1970 period would most probably have been one of mostly low-intensity fires in moorland communities in autumn and spring.

\section{Fire Regimes and Area Burnt in Different Time Periods}

As discussed above, major changes in fire regime of southwestern Tasmania have occurred over about the last 170 years. The fire regime has probably gone from one of frequent low- 
intensity fires in the moorlands with only the occasional high-intensity forest fire, to one of frequent moderate to high-intensity fires in all vegetation types, to low to mediumintensity moorland fires (see also fig. 1).

It should also be noted that there were probably few fires between about the 1830 s and 1851 , and between $1897 / 98$ and the 1930s. Although there was a considerable number of fires between the 1850 s and 1890 s (table 2), it is probable that the majority of the region was left unburnt. The deduced fire regimes during different periods are shown in table 3 .

There have been marked changes in the area of different vegetation types burnt since the 1890 s and 1930 s. As can be seen in table 4 large amounts of all of the different vegetation types were burnt in the 1890s and 1930s but, since the 1930 s, few wet eucalypt forest, rainforest, subalpine and alpine areas have been burnt.

The relatively small area burnt in the 1940 s is possibly a reflection of the very extensive 1930s fires, which would have resulted in much of the region consisting of regrowth vegetation in the 1940s (and hence being less flammable). The area of moorland burnt in the 1950s is almost entirely the result of three fires. The effects of the change in fire regime in the $1970 \mathrm{~s}$, with the introduction of extensive hazard-reduction burns, and equally the reduction in the area burnt in these hazard-reduction burns in the early 1990 s can also be seen in table 4 . The large area of moorland burnt in the 1980s is mainly the result of two fires, which together burnt more than 60000 ha (Blanks 1991).

Another effect of the reduction in the area burnt since the 1930 s is the formation of very extensive areas of oldgrowth moorland. This is because, in southwestern Tasmania, the majority of non-forested lowland vegetation types consist of buttongrass moorland, and more than $75 \%$ of these areas are more than 35 years of age (see MarsdenSmedley 1997; also table 5). The age categories in table 5 are based on the time required for selected moorland species to set seed (Marsden-Smedley 1990) and on the dynamics of moorland fuel accumulation and fire behaviour (Marsden-Smedley 1997). This increase in fire age is not restricted to buttongrass moorland vegetation types and is occurring in all of the region's vegetation assemblages.

\section{EFFECT OF CHANGES IN THE FIRE REGIME OF SOUTHWESTERN TASMANIA}

As discussed above, there have been major changes in the fire regime of southwestern Tasmania over about the last 170 years. These changes are unlikely to be the result of climatic changes since, with the exception of the last 25 years (which has been drier than the previous about 150 years, and during which time no major fires occurred in southwestern Tasmania), the climate over the last 170 years has not been unusual when compared to the previous several thousand years (Cook et al. 1992, 1996). It should also be noted that comparable conditions to those that occurred in $1897 / 98$ and 1933/34 occur about every five to ten years (Bureau of Meteorology data). As a result, these changes in fire regime are probably a reflection of changes in cultural attitudes and technology.

The aim of the Aboriginal fire management regime would have been to modify the environment to be more suitable for their utilisation. As such, it should be noted that the Aboriginal burning regime was not a natural or hazard- reduction burning regime, but rather it was closer to a habitat-management regime. It should also be noted that the generally slow rate of vegetation succession in southwestern Tasmania would mean that the distribution of the majority of the current vegetation and soil types would be the result of Aboriginal land use practices. Therefore, the current distribution of vegetation and soils in this region should not be described as "natural", and a better description would be a cultural landscape.

Considerable information as to the characteristics of the Aboriginal fire regime can also be gained from observations of the dynamics of peat formation and vegetation distributions in southwestern Tasmania. Conditions have been suitable for peat formation in southwestern Tasmania for about the past 10000 to 12000 years (Thomas 1995), with the formation of peat soils requiring 3000 to 12000 years at a rate of about $10-20 \mathrm{~mm}$ per century (Pemberton $\&$ Cullen 1995). However, due to differences in fuel moisture, fires tend to burn different amounts and types of fuel in different seasons. Spring and autumn fires normally leave a mat of unburnt thatch (often consisting of the majority of the lower parts of the fuel array), in contrast to summer fires, which typically burn most of the fuel array (Marsden-Smedley 1997). In addition, if fires occur in dry summers, the peat itself may burn (Bowman \& Jackson 1981, Marsden-Smedley 1993a). One effect of this is that significant peat formation is unlikely to occur in a regime of summer fires, due to the lack of suitable peat precursor material and the high probability that any pre-existing peat will be burnt.

The coexistence of extensive areas of buttongrass moorland in close proximity to highly fire-sensitive rainforest and alpine heaths also supports the proposal that the Aborigines must have had a tradition of lighting fires when wet scrub and forest communities were too wet to burn. This is especially the situation with rainforests and heaths containing coniferous species such as King Billy pine (Athrotaxis selaginoides), Huon pine and pencil pine (Athrotaxis cupressoides). Due to the time periods required for successional processes (Jackson 1968, Jarman et al. 1988b, Marsden-Smedley 1990) and soil formation (see above), these communities must have coexisted for thousands of years.

The fire management aim of the early Europeans was very different. Their aim was to open up the country in order to expose potential mineral deposits, improve access and to make the vegetation more economically productive. It should also be noted that the early European fire regime was almost certainly non-sustainable and was probably only maintained through the burning off of the fuel and

TABLE 5

Area of lowland non-forested vegetation in different age categories

\begin{tabular}{lcrc}
\hline & & \multicolumn{2}{c}{ Area } \\
\cline { 3 - 4 } Category & Age, years & ha & $\%$ \\
\hline Regrowth & less than 15 & 89247 & 12.7 \\
Mature & 15 to 35 & 80693 & 11.5 \\
Old-growth & greater than 35 & 534239 & 75.9 \\
\hline
\end{tabular}

Note: the majority of lowland non-forest vegetation in southwestern Tasmania is buttongrass moorland. 
soil nutrient capital which had accumulated during periods of lower fire frequencies. Evidence of this can be seen in the aerial photographs from the 1940 s, where there are extensive areas of what appear to be degraded moorland, scrub and forest. As a result of this extensive burning, the early European fire regime would have caused massive vegetation change. For example, $32 \%$ of King Billy pine, $8 \%$ of Huon pine and a significant amount of deciduous beech (Nothofagus gunnii) were destroyed by fire during this period (Brown 1988, Peterson 1990, Robertson \& Duncan 1991). There may also have been extensive areas of peat soils destroyed during this time (Pemberton 1988, 1989, Hannan et al. 1993, Pemberton \& Cullen 1995). However, the observation that extensive areas of peat soils have been lost due to European burning needs to be made with caution, since there is no quantitative evidence that the areas which currently have gravel soils ever had more extensive organic soils. This is reflected in the observations of extensive areas of gravel soils by G. A. Robinson on the south and west coasts and near the Wanderer River (Plomley 1966), J. E. Calder near the Acheron River (Calder 1849) and J.R. Scott on the Arthur and Crossing Plains and near Port Davey (Scott 1871, 1875). Therefore, it is possible that a proportion of the skeletal soils in western and southwestern Tasmania could be a product of the region's low fertility, past glacial events and/or Aboriginal fires.

It should also be noted that once rainforests have been burnt, major changes occur to their fuel arrays such that they become far more flammable. This is mainly due to increases in the amount of dead fuel, opening up of the canopy and changes to the floristics and structure of the community (Barker 1991).

In parallel to the changes reported in this paper, major changes in fire regime, resulting from changes in cultural and land-use practices, have also been reported in the rainforests, woodlands and grasslands of Patagonia. In this area, prior to the $1890 \mathrm{~s}$, the indigenous Indians practised a fire regime of frequent low-intensity fires in the xeric woodlands and grasslands with few fires in rainforests. Following the removal of the Indians in the 1890 s, European settlers introduced widespread fire to the region's rainforests in an attempt to transform the forest into grassland for the purposes of cattle ranching. Again in common with southwestern Tasmania, the success of the European's attempts to burn the rainforest communities was largely dependent on the degree of seasonal drought, with major fires occurring in the drought years of 1911 to 1917 (Kitzberger et al. 1997).

Southwest Tasmania is an area of very high cultural and ecological value, as evidenced by its World Heritage Status. Therefore, the management of the region must be targeted to maximise the positive aspects of the management regime whilst minimising the negative impacts. The Tasmanian Wilderness World Heritage Area Draft Management Plan (Parks \& Wildlife Service 1997) states that the overall main management objectives are

To identify, protect, conserve, present and, where appropriate, rehabilitate the natural and cultural values of the World Heritage Area, and to transmit that heritage to future generations in as good or better a condition than at present.

A regime of natural (i.e. lightning) fires is not going to meet these goals. This is because the slow rates of vegetation succession in southwestern Tasmania result in very long fire-free periods being required, in order to transform the vegetation to the less flammable rainforest community types. Infrequent fire would also result in the fire-adapted vegetation of the region being classified as old-growth, with the attendant problems of high fuel loads, high dead to live fuel ratios and highly continuous fuels. Under a regime of infrequent fires, when the inevitable summer fire occurred in fire-adapted vegetation, the characteristics of the fuel array would ensure that the fire had higher rates of fire spread and intensities than is normal. Such fires would also have a high probability of burning peat soils and transgressing natural boundaries and, therefore, burning fire-sensitive vegetation.

As a result, if we are to maintain and enhance the biodiversity of the wildlands of western and southwestern Tasmania, we are going to have to reintroduce fire into many of the areas which currently have a low fire frequency. However, when fire is reintroduced to these areas, it is absolutely essential that the fire regime implemented is in keeping with the ecological requirements of the vegetation being burnt. The alternative policy of not performing prescribed burning and allowing natural fires to burn (i.e. similar to the policy applying in some of the USA wilderness — Leopold et al. 1963, Kilgore 1985, Schullery 1989) is unlikely to be effective in southwestern Tasmania. Such a policy of benign neglect (Brown 1996) will not provide an adequate number of fires to maintain fire-adapted vegetation types whilst protecting fire-sensitive vegetation types. Such a policy will also require a high degree of fatalism (Blanks 1991), since it will almost certainly lead to a repeat of the situation that occurred in the $1850 \mathrm{~s}, 1890 \mathrm{~s}$ and $1930 \mathrm{~s}$, when very extensive areas of fire-sensitive vegetation were burnt.

The situation where there is a requirement for the reintroduction of fire into fire-adapted vegetation is not unique to western and southwestern Tasmania. Many other parts of the world have similar ecological problems. In northern America, over the past decade, there has been an increasing push for the restoration of wildland vegetation, often using fire (e.g. Schullery 1989, Brennan \& Hermann 1994, Mutch 1994). These strategies have both ecological and economic advantages. Therefore, in order to manage southwestern Tasmania adequately, we are going to have to be pro-active and dynamic in our management. If we follow such guidelines, then we have a reasonable chance of being able to maximise our gains whilst minimising our impacts. Not to do so, is almost certainly to degrade our wildland environment, whilst incurring increased economic costs.

\section{ACKNOWLEDGEMENTS}

This research wassupported by the Department of Geography and Environmental Studies, University of Tasmania, and the Fire Management Branch, Parks and Wildlife Service, Department of Environment and Land Management, Tasmania. In particular, I would like to acknowledge the assistance of Dylan Kendall, who coaxed the maps out of the Geographic Information System, along with Jamie Kirkpatrick and Mick Brown, who provided critical comments on the work performed in this paper. The considerable assistance obtained from the staff at the Archives Office of Tasmania and the Royal Society of Tasmania archives is also acknowledged. 


\section{REFERENCES}

ABEL, G., no date: AGAINST THE GRAIN: WITH THE HUON PINE LOGGERS OF THE WEST COAST OF TASMANIA. The Printing Press.

BARKER, M.J., 1991: The effect of fire on west coast lowland rainforest. Tech. Rep. Tasm. NRCP 7. Forestry Commission, Hobart, Tasmania, and DASETT, Canberra, ACT.

Bell A., 1983: Fire and rainforest in Tasmania. Ecos 37: 3-8.

BINKS, C.J., 1980: EXPLORERS OF WESTERN TASMANLA. Mary Fisher Bookshop, Launceston, Tasmania.

BLANKS, T., 1991: Fatalism: a cost effective approach to fire management in Southwest Tasmania. In FIFTH REGIONAL SEMINAR ON NATIONAL PARKS AND WILDLIFE MANAGEMENT TASMANIA, 1991. Department of Parks, Wildlife and Heritage, Hobart, Tasmania.

Bowman, D.M.J.S., 1995: Why the skilful use of fire is critical for the management of biodiversity in Northern Australia. In Rose, D.B. (Ed.): COUNTRY IN FLAMES. Proceedings of the 1994 symposium on biodiversity and fire in North Australia. Biodiversity Series, Paper No. 3. Biodiversity Unit, Department of the Environment, Sport and Territories, Canberra, Australia and the North Australia Research Unit, Australian National University, Canberra, Australia.

BOWMAN, D.M.J.S. \& JACKSON, W.D., 1981: Vegetation succession in Southwest Tasmania. Search 12: 358-362.

BRAITHWATTE, R.W., 1995: A healthy savanna, endangered mammals and Aboriginal burning. In Rose, D.B. (Ed.): COUNTRY IN FLAMES. Proceedings of the 1994 symposium on biodiversity and fire in North Australia. Biodiversity Series, Paper No. 3. Biodiversity Unit, Department of the Environment, Sport and Territories, Canberra, Australia and the North Australia Research Unit, Australian National University, Canberra, Australia.

Brennan, L.A. \& Hermann, S.M., 1994: Prescribed fire and forest pests: solutions for today and tomorrow. J. For. 92: 34-37.

BRIDLE, K.L. \& KirKPATRICK, J.B., 1997: Local environmental correlates of variability in the organic soils of moorland and alpine vegetation, Mt Sprent, Tasmania. Aust. J. Ecol. 22: 196-205.

BROWN, M.J., 1988: DISTRIBUTION AND CONSERVATION OF KING BILLY PINE. Forestry Commission, Hobart, Tasmania.

Brown, M.J., 1996: Benign neglect and active management in Tasmania's forests: a dynamic balance or ecological collapse? For. Ecol. Manage. 85: 279-289.

BURN, D., 1842: Narrative of the overland journey of Sir John and Lady Franklin and party from Hobart Town to Macquarie Harbour. In Mackaness, G. (Ed.): Aust. Hist. Monogr. XVI (new series), published 1977.

Calder, J.E., 1847: Copy of a letter of Mr J E Calder upon the existence of natives in unexplored parts of Tasmania in 1847. RS 19/6, Royal Society of Tasmania Archives.

Calder, J.E., 1849: Some account of the country lying between Lake St Clair and Macquarie Harbour. Tasm. J. Nat. Sci., Agric., Stat. 3: 415-429.

Calder, J.E., 1860a: Topographical sketches of Tasmania. Number 3. Mercury, 27 Jan. 1860.

Calder, J.E., 1860b: Topographical sketches of Tasmania. Number 5. Mercury, 6 Mar. 1860.

CALDER, J.E., 1860c: Exploration. Some account of the country between Hamilton and Lake Pedder. Mercury, 13 Apr. 1860 .

Condor, H., 1915: The wild west. Port Davey to Macquarie Harbour. One hundred miles of track. Mercury, $31 \mathrm{Mar}$. 1915.
Cook, E.R., Bird, T., Peterson, M., Barbetti, M., Buckley, B., D'Arrigo, R. \& Francey R., 1992: Climatic change over the last three millennium in Tasmania reconstructed from tree-rings. Holocene 2: 205-217.

COOK, E.R., BuckLeY, B. \& D'ARRIGo, R., 1996: Inter-decadal climate oscillations in the Tasmanian sector of the Southern Hemisphere: evidence from tree rings over the last three millennia. In Jones, P.D., Bradley, R.S. \& Jouzel, J. (Eds): CLIMATE VARIATIONS AND FORCING MECHANISMS OF THE LAST 2000 YEARS. NATO ASI vol. 141.

Cosgrove, R., Allen, J. \& Marshall, B., 1994: Late Pleistocene human occupation in Tasmania: reply to Thomas. Aust. Archaeol. 38: 28-35.

CotTon, H., 1850: Report on access routes and pasture land in southwest Tasmania. Colonial Survey Office, Tasmania. CSO 24/130/4347/368-372, Archives Office of Tasmania.

Cotton, H., 1851: Government Notice No. 38. General report on the progress of operations west of the Derwent. Hobart Town Gazette, 8 Apr. 1851.

Counsel, E.A., 1898: Timber industry in Tasmania. Parliament Tasm. J. 1898, report 48 .

Davies, R.H., 1846: On the Aborigines of Van Diemans Land. Tasm. J. Nat. Sci., Agric. Stat. 2: 409-420.

Derartment of Mines Tasmania, 1960. SOUTH WEST TASMANIA. 1:158 400 sketch map.

FLANAGAN, R., 1985: A TERRIBLE BEAUTY. HISTORY OF THE GORDON RIVER COUNTRY. Greenhouse Publications Pty Ltd, Melbourne, Victoria.

Frankland, G., 1835: Account of a trip to the middle Gordon and Huon River plains. Hobart Town Courier, 27 Mar. 1835.

FRANKLAND, G., 1836: Account of tracks to Lake St Clair and the Huon River. Hobart Town Courier, 15 July 1836.

FRANKS, S.M., 1958: Land exploration in Tasmania, 1824-1842 with special reference to the Van Diemen's Land Company. Unpubl. MA thesis, Univ. Tasm.

GilberT, J.M., 1978: Notes on forest classification and fire occurrence. Lower Gordon Environmental Investigation. Unpubl. rep. Hydro Electric Commission, Hobart, Tasmania.

Gilbert, J.M., 1979: Fires in the Tasmanian bush. Tasm. Tramp 23: $118-122$

GoodwIN, J., 1828: Goodwin's statement. CSO 1/276/6658, Archives Office of Tasmania.

Gould, C., 1862a: Macquarie Harbour. Mr. Gould's report. Legislative Council J.vol. VII, rep. 20, Hobart, Tasmania.

Gould, C., 1862b: Safety of Mr. Gould's party. Discovery of a gold field and valuable mineral country. Mercury, 14 May 1862.

GowlLAND, R. \& GOWLLAND, K., 1976: TRAMPLED WILDERNESS. THE HISTORY OF SOUTH-WEST TASMANIA. Third edn, 1986. Richmond Printers, Devonport, Tasmania.

HALES, R.C., 1918: Unpublished track report: Exploration of Gordon-Tyenna track. NP 21/14, Archives Office of Tasmania.

Hannan, D.G., Banks, M.R., Kiernan, K., Pemberton, M. \& Williams, E., 1993: Physical environment - geology, geomorphology and soils. In Smith, S.J. \& Banks, M.R. (Eds): TASMANIAN WILDERNESS - WORLD HERITAGE VALUES. Royal Society of Tasmania, Hobart, Tasmania.

HAY, J., 1871: Exploration trip to the west. Mercury, 24 Mar. 1871 .

HiL.Ls, L., 1914: Geological reconnaissance of the country between Cape Sorell and Point Hibbs. Geological Survey Bulletin 18. Department of Mines, Hobart, Tasmania.

Howard, C., 1927: Notes on the country between Low Rocky Point and Fitzgerald. Report of the Director of Mines. Parl. Tasm. J. 1927, rep. 4. 
Innes, E.G., 1887: The Derwent Vallcy Track to Linda. Tasm. Mail, 29 Jan. 1887.

INNES, E.G., 1896: Route to the west coast: Report of Mr. Surveyor Innes upon the country between Mount Humboldt and the head of the navigable water upon the River Gordon. Parl. Tasm. J. 1896, rep. 74.

JACKSON, W.D., 1968: Fire, air, water and earth - an elemental ecology of Tasmania. Proc. Ecol. Soc. Aust. 3: 9-16.

JACKSON, W.D., 1981: THE VEGETATION OF TASMANIA. Botany Department, University of Tasmania.

Jarman, S.J., Kantvilas, G. \& Brown, M.J. 1988a: A preliminary study of stem ages in buttongrass moorlands. Res. Rep. 3, Tasmanian Forest Research Council Inc., Hobart, Tasmania.

Jarman, S.J., Kantvilas, G. \& Brown, M.J., 1988b: Buttongrass moorland in Tasmania. Res. Rep. 2, Tasmanian Forest Research Council Inc., Hobart, Tasmania.

Johannes, C.E. \& Brown, A.V., 1992: W.C. PIGUENIT 18361914 RETROSPECTIVE. Tasmanian Museum and Art Gallery, Hobart, Tasmania.

Johnston, B., 1935: To the Jane River. Tasm. Tramp 4: 5-12.

JONES, D., 1881: Report on track from Macquarie Harbour to upper Huon. Parl. Tasm. J. 1881, report 126.

JONES, R., 1969: Fire stick farming. Aust. Nat. Hist. 16: $224-$ 228.

Jones, R., 1993: Discovery of a Pleistocene world. In Smith, S.J. \& Banks, M.R. (Eds): TASMANIAN WILDERNESS WORLD HERITAGE VALUES. Royal Society of Tasmania, Hobart, Tasmania.

JonEs, R., 1995: Mindjongork: legacy of the firestick. In Rose, D.B. (Ed.): COUNTRY IN FLAMES. Proceedings of the 1994 symposium on biodiversity and fire in North Australia. Biodiversity Ser., Pap. 3. Biodiversity Unit, Department of the Environment, Sport and Territories, Canberra, Australia and the North Australia Research Unit, The Australian National University, Canberra, Australia.

Kelly, J., 1816: First discovery of Port Davey and Macquarie Harbour. Pap. Proc. Roy. Soc. Tasm. 1920.

Kiernan, K., Jones, R. \& Ranson, D., 1983: New evidence from Fraser Cave for glacial age man in south-west Tasmania. Nature 301: 28-32.

KILGORE, B.M., 1985: The role of fire in wilderness: a state-ofknowledge review. In Lucas, R.C. (Ed.): Proceedings of the National Wilderness Research Conference. USDA Forest Service General Tech. Rep. INT-220. Intermountain Forest and Range Experimental Station, Ogden Utah, USA.

KirKPATRICK, J.B., 1982: Phytogeographical analysis of Tasmanian alpine floras. J. Biogeogr. 9: 255-271.

KirKPATRICK, J.B., 1984a: Altitudinal and successional variation in the vegetation of the northern part of the West Coast Range, Tasmania. Aust. J. Ecol. 9: 81-91.

KirkPatrick, J.B., 1984b: Tasmanian high mountain vegetation II - Rocky Hill and Pyramid Mountain. Pap. Proc. Roy. Soc. Tasm. 1 18: 5-20.

KirkPatrick, J.B. \& Brown, M.J., 1987: The nature of the transition from sedgeland to alpine vegetation in southwest Tasmania. I. Altitudinal vegetation change on four mountains. J. Biogeogr. 14: 539-549.

KirkPatrick, J.N. \& Harwood, C.E., 1980: Vegetation of an infrequently burned Tasmanian mountain region. Proc. R. Soc. Vict. 91: 79-107.

KirKPATRICK, J.B. \& BROWN, M.J., 1991: RESERVATION ANALYSIS OF TASMANIAN FORESTS. Resource Assessment Commission Forest and Timber Inquiry Consultancy Series No. FTC91/16.

Kirkpatrick, J.B., Nunez, M., Bridle, K. \& Chladil, M.A., 1996: Explaining a sharp transition from sedgeland to alpine vegetation on $\mathrm{Mt}$ Sprent, southwest Tasmania. J. Veg. Sci. 7: 763-768.
Kitzberger, T., Veblen, T.T. \& Villalba, R., 1997: Climatic influences on fire regimes along a rain forest-to-xeric woodland gradient in northern Patagonia, Argentina. J. Biogeogr. 24: 35-47.

KOHEN, J.L., 1995: ABORIGINAL ENVIRONMENTAL IMPACTS. University of New South Wales Press, Sydney, Australia.

Leopold, A.S., Cain, S.A., Cottam, C.M., Gabrielson, I.N. \& KimbaLl, T.L., 1963: Wildlife management in the national parks. Trans. North Am. Wildland Nat. Resour. Conf. 24: $28-45$.

LEwis, H.T. \& MCPARTLAN, F., 1859: Diary of Mr Henry Tayler Lewis and Mr F. McPartlan. Mercury, 2 June 1859.

LitTLE, J., 1833: Account of a journey from Macquarie Harbout to the Huon. Hobart Town Chron., 26 Mar. 1833.

MarriotT, R., 1908: Report on track connecting Webster's Track with Great Western Railway Track. Department of Lands and Surveys: report for the yeat ended 30th June 1908. Parl. Tasm. J. 1908, rep. 13.

MARSDEN, E.A., 1898: Unpublished report regarding the construction of the track from Frodshams Pass to Bathurst Harbour. Lands and Survey Department, Hobart, Tasmania. LSD 6/194/849c, Archives Office of Tasmania.

Marsden-Smedley, J.B., 1990: The ecology of moorland-copse boundaries in southwest Tasmanian oligotrophic environments. Unpubl. Hons thesis, Dep. Plant Sci., Univ. Tasm.

Marsden-Smediey, J.B., 1993a: Fuel characteristics and fire behaviour in Tasmanian buttongrass moorlands. Parks \& Wildl. Serv., Dep. Environ. Land Manage., Hobart, Tasmania.

MARSDEN-SMEDley, J.B. 1993b: Orange-bellied parrot recovery plan: operational prescriptions for habitat management burns. Unpubl. rep. Parks \& Wildl. Serv., Dep. Environ. Land Manage., Hobart, Tasmania.

Marsden-Smedley, J.B., 1997: Fire and fuel in Tasmanian buttongrass moorlands: regimes, characteristics, behaviour and management. Unpubl. PhD thesis, Dep. Geogr. Environ. Stud., Univ. Tasm., Hobart, Tasmania.

Marsden-Smedley, J.B., Catchrole, W.R. \& Pyrke, A., 1998: Unbounded burning in Tasmanian buttongrass moorlands: fire behaviour modelling and operational prescriptions. Rep. Parks Wildl. Serv., For. Tasm. and Tasm. Fire Serv.

McRae, M.D., 1960: Port Davey and the South-west. Pap. Proc. Tasm. Hist. Res. Assoc. 8: 46-50.

McShane, I., 1982: T.B. Moore - a bushman of learning. Unpubl. Hons thesis, Univ. Tasm.

Meredith, G.C., 1876:JOURNAL OF A PROSPECTING TRIP TO WESTERN TASMANIA. AOT NS718/1.

MEREDITH, G.C., 1898: JOURNAL OF A PROSPECTING TRIP TO SOUTHWESTERN TASMANIA. AOT NS718/9.

MoORe, T.B., 1887: Account of a trip to Frenchmans Cap in 1887. Reprinted in 1970. Skyline 20: 5-9.

Mutch, R.W., 1994: Fighting fire with prescribed fire: a return to ecosystem health. J. For. 92: 31-33.

PARKS AND WILDLIFE SERVICE, 1997: TASMANIAN WILDERNESS WORLD HERITAGE AREA DRAFT MANAGEMENT PLAN. Parks and Wildlife Service, Department of Environment and Land Management, Hobart, Tasmania.

Pemberton, M., 1988: Soil erosion between Birchs Inlet and Elliott Bay, southwestern Tasmania. Pap. Proc. R. Soc. Tasm. 122: 109-114.

Pemberton, M., 1989: Land systems of Tasmania region 7 Southwest. Department of Agriculture, Hobart, Tasmania.

Pemberton, M. \& Cullen, P., 1995: Impacts of fire on soils in Tasmania. In Blanks, A.B. (Ed.): BUSHFIRE 95. Proceedings of the Australian Bushfire Conference. 27-30 Sep. 1995, Hobart, Tasmania. Jointly published by Parks and Wildlife Service, Forestry Tasmania and Tasmania Fire Service. 
PerRin, G.S., 1887: Wood and forests of Tasmania: report of the Conservator of Forests, 1886-7. Parl. Tasm. J. 1887, report 59.

Perrin, G.S., 1898: Forests of Tasmania: their conservation and future management. Parl. Tasm. J. 1898, report 48.

PeTERson, M., 1990: DISTRIBUTION AND CONSERVATION OF HUON PINE. Forestry Commission, Hobart, Tasmania.

PHiLP, J.E., 1937: Unpublished manuscript: Where tracks are made. NS 21/22/1, Archives Office of Tasmania.

Piguenit, W.C., 1892: Among the Western Highlands of Tasmania. Report of the Fourth Meeting of the Australasian Association for the Advancement of Science, 1892, Hobart, Tasmania. Trans. Australas. Assoc. Adv. Sci. Government Printer, Tasmania.

Plomley, N.J.B., 1966: FRIENDLY MISSION: THE TASMANIANJOURNALS AND PAPERS OF GEORGE AUGUSTUS ROBINSON 1829-1834. Tasmanian Historical Research Association, Hobart, Tasmania.

Plomley, N.J.B., 1991: JORGEN JORGENSON AND THE ABORIGINES OF VAN DIEMEN'S LAND. Blubberhead Press, Hobart, Tasmania, Australia.

ROBERTSON, D.I. \& DUNCAN, F., 1991: DISTRIBUTION AND CONSERVATION OF DECIDUOUS BEECH. Forestry Commission Tasmania and Department of Parks, Wildlife and Heritage, Hobart, Tasmania.

RoTH, H.L., 1899: THE ABORIGINES OF TASMANIA. Fullers Bookshop, Hobart, Tasmania.

SChullery, P., 1989: The fires and fire policy. The drama of the 1988 Yellowstone fires generated a review of national policy. BioScience 39: 686-694.

ScotT, J.R., 1871: Arthur Plains and Port Davey. Mercury, 5 Apr. 1871.

Scott, J.R., 1875: Port Davey in 1875. Pap. R. Soc. Tasm.

SHARLAND, W.S., 1861: Rough notes of a journal of expedition to the westward in 1832. Survey Office Reports, Legislative Council Journal vol. VI, part 1, rep. 16, Hobart, Tasmania.

STATE EMERGenCy SeRVice, 1990: History of emergency events issue 1. July 1990. State Emergency Service, Hobart, Tasmania.

StockTon, J., 1982: Fires by the seaside: historic vegetation changes in northwestern Tasmania. Pap. Proc. R. Soc. Tasm. 116: 53-66.

ThiRKelL, R.A.C., 1908: Report on track from Mt Arrowsmith to Gordon River. Department of Lands and Surveys: report for the year ended 30th June 1908. Parl. Tasm. J. 1908, rep. 13.

Thomas, I., 1991: The Holocene archaeology and palaeoecology of Northeastern Tasmania, Australia. Unpubl. PhD thesis, Univ. Tasm.

THOMAS, I., 1993a: Late Pleistocene environments and Aboriginal settlement patterns in Tasmania. Aust. Archacol. 36: 111 .
Thomas, I., 1993b: The Central Highlands. In Smith, S.J. \& Banks, M.R. (Eds): TASMANIAN WILDERNESS WORLD HERITAGE VALUES. Royal Society of Tasmania, Hobart, Tasmania.

THomas, I., 1995: Where has all the forest gone: new pollen evidence from Melaleuca Inlet in SW Tasmania. In Dixon, G. \& Aitkin, D. (Eds): Monash Univ. Publ. Geogr. 45: 295-301.

Thomas, I. \& Hope, G., 1994: An example of Holocene vegetation stability from Camerons Lagoon, a near treeline site on the Central Plateau, Tasmania. Aust. J. Ecol. 19: 150158.

ThwaITES, J.B., 1934: Frenchman's Cap. Tasm. Tramp 3: 5-11.

Tully, W.A., 1859: The western country. Mercury, 26 Apr. 1859.

Twelvetrees, W.H., 1906: Unpublished report on the Cox Bight Tin field. AC 19. Archives Office of Tasmania.

Twelvetrees, W.H., 1908: Report by Mr. W. H. Twelvetrees, Government Geologist. Department of Lands and Surveys: report for the year ended 30th June 1908. Parl. Tasm. J. 1908, rep. 13.

Twelvetrees, W.H. 1909: Western exploration: report on journey to the Gordon River by Mr. W. H. Twelvetrees, Government Geologist. Department of Lands and Surveys: report for the year ended 30th June 1909. Parl. Tasm. J. 1909 , rep. 21.

Twelvetrees, W.H., 1915: Annual report of the Government Geologist. Department of Mines, Hobart, Tasmania.

Tyler, W.H. \& Harper, W.T., 1906: Cox's Bight. Mercury, 19 Apr. 1906.

WALKER, J.B., 1887: Walk to the west. In Stoddart, M. (Ed.): JOURNAL OF A TRIP TO TASMANIA'S WEST COAST, I7 FEBRUARY TO 5 MARCH 1887. Royal Society of Tasmania.

WaLlaCE, W.H., 1901: Report of the Secretary for Mines for 1900-1901. Parl. Tasm. J. 1901, rep. 4.

WARD, L.K., 1908: Report by L. K. Ward, Assistant Government Geologist. Department of Lands and Surveys: report for the year ended 30th June 1908. Parl. Tasm. J. 1908, rep. 13.

WARD, L.K. 1909: Report by L. K. Ward, Assistant Government Geologist. Department of Lands and Surveys: report for the year ended 30th June 1909. Parl. Tasm. J. 1909, rep. 21 .

WARREN, R., 1936: Diary of two wretched females on a trip to Frenchman's Cap. Tasmanian Tramp 5: 44-48.

(accepted 11 November 1997) 